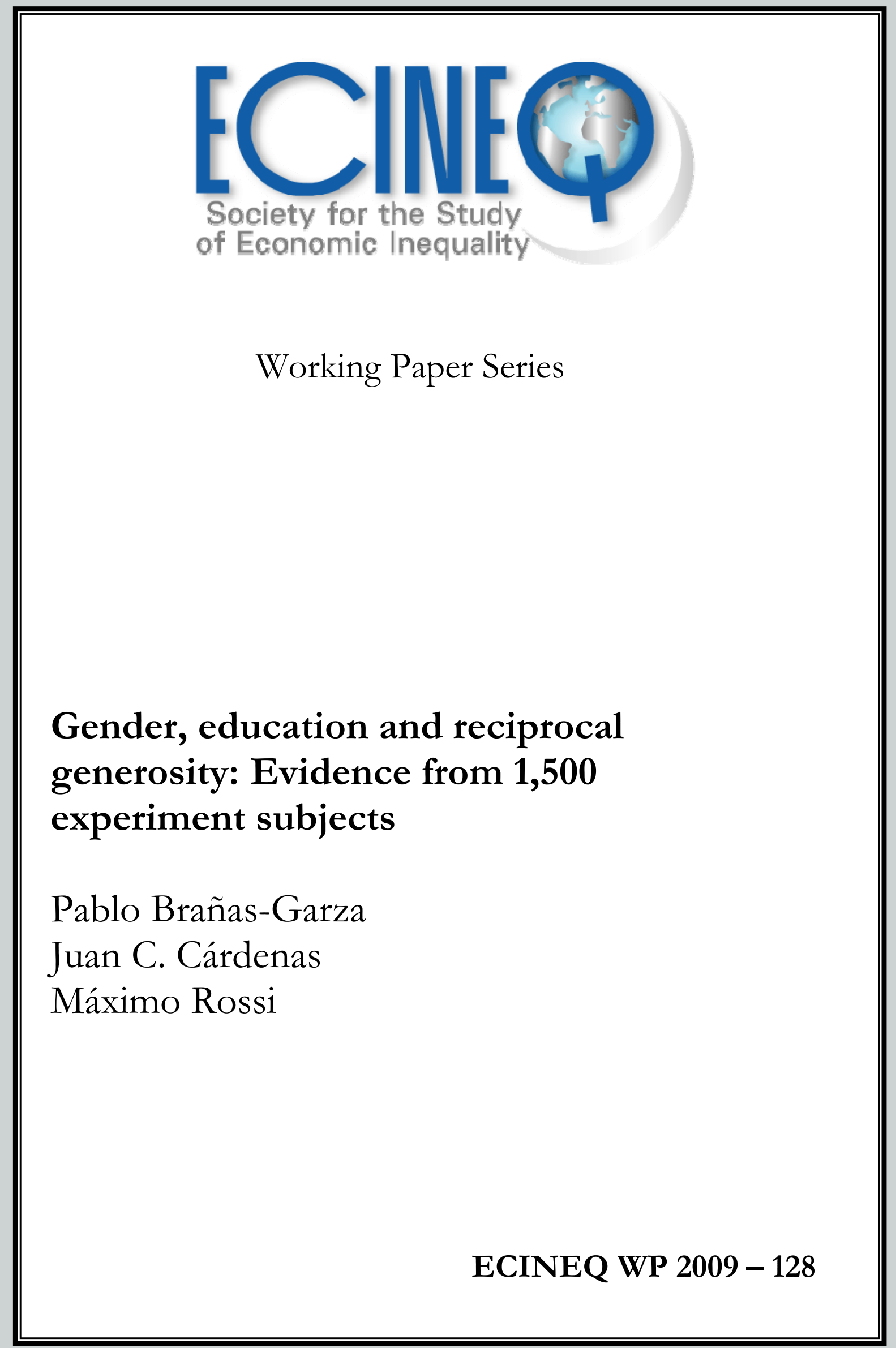




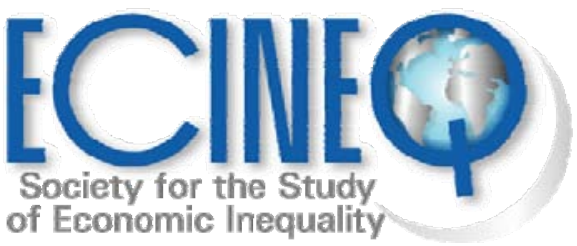

ECINEQ 2009-128

September 2009

www.ecineq.org

\title{
Gender, education and reciprocal generosity: Evidence from 1,500 experiment subjects ${ }^{*}$
}

\author{
Pablo Brañas-Garza \\ Universidad de Granada (Spain) \\ Juan C. Cárdenas \\ Universidad de los Andes (Colombia) \\ Máximo Rossi † \\ Universidad de la República (Uruguay)
}

\begin{abstract}
There is not general consensus about if women are more or less generous than men. Although the number of papers supporting more generous females is a bit larger than the opposed it is not possible to establish any definitive and systematic gender bias. This paper provides new evidence on this topic using a unique experimental dataset. We used data from a field experiment conducted under identical conditions (and monetary payoffs) in 6 Latin American cities, Bogotá, Buenos Aires, Caracas, Lima, Montevideo and San José. Our dataset amounted to 3,107 experimental subjects who played the Trust Game. We will analyze the determinants of behavior of second movers, that is, what determines reciprocal generosity.

In sharp contrast to previous papers we found that males are more generous than females. In the light of this result, we carried out a systematic analysis of individual features (income, education, age, etc.) for females and males separately. We found differential motivations for women and men. Third, we see that (individual) education enhances pro-social behavior. Lastly, we see that subjects' expectations are crucial.
\end{abstract}

Keywords: Reciprocal altruism, gender, education

JEL Classification: C93, D64, J16

\footnotetext{
* Pablo Brañas-Garza wishes to thank CICYT (SEJ2007-62081/ECON) for their financial support; Juan Camilo Cardenas is grateful for financial support from the Inter-American Development Bank and its RES department. Hugo Nopo and Alberto Chong provided valuable input in the project design that the field work is based on, and Natalia Candelo and Sandra Polanía coordinated the field work across the six cities.

† Corresponding author: maximo.rossi@gmail.com
} 


\section{1) Motivation}

Reciprocity plays a central role in daily life. In a whole range of contexts from markets to intrahousehold relationships, a vast number of individual actions might be explained as being simply responses to previous actions. Individuals are (not) generous to those who previously behaved generously (selfishly) to them. At the same time, people are able to anticipate the consequences of their actions and therefore behave nicely in order not to provoke revenge from others or just in pursuit of premiums (Rabin, 1993).

The Trust Game ${ }^{1}$ mimics the above situation. Player 2 has the chance to reciprocate (behave kindly) after player 1 has given him/her some money. Although the Nash equilibrium predicts a zero return from player 2 to player 1, the experiment evidence supports reciprocal behavior: individuals who receive more are more likely to give more in return, that is, generosity enhances generosity. Furthermore, the evidence also shows that a substantial fraction of player 1 individuals will send a positive fraction of money in anticipation of reciprocal behavior from strangers they have not signed a contract with.

Player 1 and 2 behaviors have both been systematically studied in the laboratory and in the field. Typically these studies are based on a sample of 50-100 participants, and consequently they suffer from two basic limitations: statistical analysis should be limited to non-parametric techniques and the representativity of the sample is low. ${ }^{2}$

In this paper we explore RECIPROCATION: the percentage of money that player 2 returns to player 1 . Specifically we want to discuss reciprocation as generosity, whereby individuals in the player 2 situation are facing a "signaled" dictator game. The main contribution of this paper resides in the quality and size of the sample, the precise study on gender, the extent of the socio-demographics variables and the use of ordered probit models.

We found a strong gender bias in reciprocal behavior: males are more generous than females. In the light of this result, we carried out a systematic analysis of individual features (income, education, age, etc.) for females and males separately. We extended the analysis to include subjects' expectations, ${ }^{3}$ and we found differential motivations for women and men.

\footnotetext{
${ }^{1}$ The first mover decides how much money to pass to the second mover. All money passed is increased by a factor, $M>1$, and the second mover then decides how much of this money to return to the first mover. The Nash equilibrium for selfish preferences is to pass nothing, since a self-interested person would return nothing in the final stage. The game highlights issues of reciprocity and strategy (Berg et. al 1995).

${ }^{2}$ Typically we have many observations of university students but none of adults from different households.

${ }^{3}$ Chaudhuri and Gangadharan (2003) also elicited expectations for TG players. However they focused on first movers: the amount of returned money they expect from second movers. We concentrated on second mover expectations.
} 
The existence of a gender effect on reciprocal behavior has been studied before, but the results have been contradictory. ${ }^{4}$ Croson \& Buchan (1999) found that women return a large percentage of the pie and, using a post-experimental questionnaire, they found that $57 \%$ of women (as against $24 \%$ of men) felt extremely obligated "to return at least as much to the proposer as the proposer sent me". Cox (2002) found exactly the opposite, that men return more than women, and he found that men exhibit positive reciprocity but women do not. Chaudhuri and Gangadharan (2003) -using experimental subjects playing as proposers and responders- found weak evidence (significant at 10\%) in favor of the thesis that women are more generous.

Our paper, which supports Cox (2002) in that men emerge as more generous than women, contradicts the results of Croson \& Buchan (1999) and Chaudhuri and Gangadharan (2003). It is worth noting that in all three papers mentioned above, sample size was under 100 responders, who were university students.

In a recent paper, Cox and Deck (2006) state that social distance is important in gender behavior, as are social cost and monetary costs. They found that women are more responsive to the total economic and social costs of generous behavior. Our dataset does not allow comparisons of social distance (we suppose "enormous" because of the composition of each session but "reduced" because of the presence of the experimenter) but by using the strategy method we were able to explore differential behaviors when cost varies. We found that men are more generous when the relative cost of the money is less. This is consistent with Andreoni and Verterlund (2001) but not with the above-cited paper by Cox and Deck (2006).

We used data from a field experiment conducted under identical conditions (and monetary payoffs) in 6 Latin American cities, Bogotá, Buenos Aires, Caracas, Lima, Montevideo and San José. Our dataset amounted to 3,107 experimental subjects.

The experiment was designed controlling by age, social groups, gender composition and so on, so our sample was very heterogeneous in terms of demographic and socio-economic characteristics. This means that our dataset is large and heterogeneous enough to provide a relevant analysis.

Our experimental setting consisted of several stages. The first was the Strategy Method Trust Game. Player 2 has to decide how much money he/she will return to player 1 in several

\footnotetext{
${ }^{4}$ There is a vast amount of literature connecting generosity in the Dictator Game and Gender (see Croson and Gneezy (2006) and Eckel and Grossman (2006) for detailed surveys). Most of these papers report that women are more generous and only a very few show that men are more generous (see D'Exelle 2008). Aguiar et al. (forthcoming) studies whether women are expected to be more generous than men, and they found that women do consider that they are more generous in $80 \%$ of cases whereas men do not expect any gender bias.
} 
scenarios $(0,25 \%, 50 \%, 75 \%$ and $100 \%$ of the endowment sent by player 1$)$. In total there are 5 "returns" from player 2 to player 1 . We had 1,549 responders. We defined three central measures (free-riding, exact return and sharing the surplus) to explore reciprocal behavior. We also explored the determinants of reciprocal behavior for each scenario. The complete analysis was repeated for females and males separately.

Our results are conclusive

1) Beliefs (expectations in $1^{\text {st }}$ player actions) play a crucial role in reciprocal behavior: optimism enhances reciprocity.

2) Women are more selfish than men when sharing the surplus but are fairer: i.e. women are more likely to return player 1's investment to him, but also more likely to keep the generated surplus for themselves.

3) Selfish and generous behavior in females and males have different motivations. For instance, whether marital status is relevant for women, and we found that household responsibilities are only significant for males.

4) Individual level of education enhances pro-social values (reciprocity) and destroys antisocial patterns. Better-educated subjects punish selfish player 1 individuals who sent $0 \%$ of the pie.

This paper is organized as follows: in section 2 we give a complete explanation of the design of the experiment, in section 3 we give our results, in section 4 we explore the differences between our results and those of previous related papers, and in section 5 we draw some conclusions.

\section{2) Design of the experiment, procedures \& empirical strategy}

\subsection{Design of the experiment}

During the study that generated the data set (IADB, 2007) a representative sample of individuals from heterogeneous urban societies in six Latin American capital cities were recruited in the streets and invited to participate voluntarily in a set of economic experiments, and they were offered immediate substantial economic incentives to participate. In each session there were around twenty people who did not know each other. The interactions among the individuals took place in a controlled setting where we could observe how incentives, institutions and norms affected behavior, which is consistent with field experiment approaches (Carpenter, et al. 2005; Harrison and List, 2004). The aim of this design was to 
capture how the daily context of the participants and their interaction with other citizens of the same city but ultimately with different backgrounds affected their propensity to trust and their trustworthiness (see Lewitt and List, 2007).

The design of the experiment was based on 4 activities (A.1 to A.4) that the participants carried out by making individual decisions with economic outcomes for themselves and for the others in the group. ${ }^{5}$ In our design there is a session in which a group of about 20 people are together in a room for 2-3 hours, and they make choices in a series of 4 activities or games from which they earn money.

The sequence of activities can be briefly described as follows:

- Activity 1 (TRUST GAME): all participants in the session are randomly assigned in pairs to play a one-shot Trust Game. The players with role 1 (players 1 ) are located in one room and players 2 in another. Identities are never revealed, but each player knows the demographic characteristics of his/her counterpart (age, gender, education and socio-economic level - hereafter SEL). The game is played using the strategy method where player 2 must decide the amounts he will return to player 1 for each possible offer from player $1(0,25 \%, 50 \%, 75 \%$ and $100 \%$ of the endowment sent). Once player 1 chooses the amount to be sent from his/her endowment, and player 2 has revealed his return for each possible case, the choices can be matched.

\section{- Activity 2 (VCM) $^{6},{\text { Activity } 3 \text { ( RISK GAMES) }{ }^{7} \text {, Activity } 4 \text { (RISK POOLING) }}^{8}$}

At the end of the above activity the monitors randomly select one of the activities to be paid, and while one monitor calculates individual earnings and calls each participant in private, the

\footnotetext{
${ }^{5}$ See Candelo and Polonia (2007) for details and Cárdenas et al. (2008) for the overall project. Instructions are available upon request.

${ }^{6}$ All participants now gathered in a single room to participate in a Voluntary Contributions Mechanism or Public Goods game, where each player has a token that he can keep or invest in a group project. If a player keeps the token he/she earns an amount, say $\$ 10$. If he invests the token in the group project, his and the other tokens in the group account yield a return of $\$ 1$ for every participant in the group. A player who keeps the token also receives $\$ 1$ $x$ the number of tokens in the group account. Before the players make their individual and private decisions about whether or not they will contribute to the group, the monitor explains verbally and also writes up on the board what the composition of the group is (gender, age, education and SEL). The monitor also requests every participant to write down a prediction of what fraction of the group will cooperate. The Marginal Per Capita Return of the game is 0.10 .

${ }^{7}$ Each player individually makes decisions over 3 games that measure individual attitudes to risk, ambiguity and losses. The games are based on six 50/50 lotteries that increase in both expected value and variance.

${ }^{8}$ Each player can choose either to join a group that will have equal shares in the gains from another risk aversion game, or to play the risk aversion game individually. Once the participants have made this decision, the total number of people who have decided to join the group is announced and then they decide about the risk choice.
} 
rest of the monitors interview each participant and fill in an individual survey form with detailed information on their background and opinions about various dimensions of social exclusion.

\subsection{Group composition by sessions}

It is important to highlight that the people attending each session were recruited using the criteria of social heterogeneity, and in each city we had at least 25 sessions that varied in degree of heterogeneity, particularly with respect to socio-economic level.

One of our main goals was to observe the effect of social heterogeneity on individuals' decisions in these experiments. Therefore it was crucial to make the social composition of each group in each particular session as distinctive and clear as possible.

We were able to use the data for our analysis of the trust game because each player knew some of his counterpart's characteristics. ${ }^{9}$ When the participants first arrived the experimenter already had basic socio-economic data about them, namely their gender, age, education level and socio-economic level based on the stratification of each city. In each pair, the players were shown a card with each other's gender, age, education level and SEL but they did not know each other's identity during the session or after it finished. During the session the participants met in one room where they could see each other, but they were not allowed to communicate. During the session they received information about the other participants in that particular group, depending on the specific activity.

Our project was based on experiments and surveys conducted in 6 Latin American cities: Bogotá, Buenos Aires, Caracas, Lima, Montevideo and San José. In each city a team of researchers with experience in survey and field methods was selected to be trained and to conduct the experiments in their own city. Each city team agreed to sample more than $\mathbf{5 0 0}$ participants from their cities, and conduct more than 25 sessions with these participants, for a total of 159 sessions (see table 1).

The local team in each city designed a stratified sample from the population of their city based on criteria of socio-economic level, education, gender and age. Then each team conducted its sessions with the following requirements:

- at least 4 sessions were conducted with homogenous groups of an average of 20 people

\footnotetext{
${ }^{9}$ Cardenas el al. (2008) ran an extensive study of how knowledge of some features of each player's counterpart affects decisions.
} 
- there were 2 homogenous sessions with high SEL participants and 2 with low SEL

- the rest of sessions had different degrees of social heterogeneity

More than 3,100 people in the six cities participated, thus providing a unique data set that combined detailed data on their socio-economic and demographic background with behavioral data from their decisions during the experiments. Each of the city teams conducted sessions of various group sizes ranging from 9 to 38 people, with a mean of 22 people in each session ${ }^{10}$. Each of these sessions followed the same protocol, which was developed during the project for one session, and had the same sequence of activities.

Table 1 shows the features of the sessions by cities and gives the participants' socio-demo variables in each case.

Table 1: Socio-demographic variables

\begin{tabular}{|c|c|c|c|c|c|c|c|}
\hline & Bogotá & B. Aires & Caracas & Lima & Montevideo & San José & Total \\
\hline N (participants) & 567 & 498 & 488 & 541 & 580 & 435 & 3109 \\
\hline$\%$ Females & 58 & 51 & 55 & 52 & 56 & 61 & 54 \\
\hline \multicolumn{8}{|l|}{ AGE } \\
\hline Average & 36.5 & 39.63 & 33.65 & 34.81 & 41.31 & 37.25 & 37.26 \\
\hline (Min-Max) & $(17-72)$ & $(17-72)$ & $(17-72)$ & $(17-76)$ & $(17-72)$ & $(17-80)$ & $(17-80)$ \\
\hline Std.Dev & 13.29 & 15.20 & 12.54 & 12.86 & 15.98 & 15.88 & 14.57 \\
\hline \multicolumn{8}{|l|}{ Years of EDUCATION } \\
\hline Average & 4.77 & 5.30 & 5.81 & 5.28 & 4.20 & 4.00 & 4.89 \\
\hline (Min-Max) & $(1-10)$ & $(2-10)$ & $(2-10)$ & $(0-10)$ & $(0-10)$ & $(0-10)$ & $(0-10)$ \\
\hline Std.Dev & 2.01 & 1.88 & 1.82 & 2.08 & 2.01 & 2.30 & 2.12 \\
\hline \multicolumn{8}{|l|}{ SOC-ECON Level } \\
\hline$\%$ low & 42 & 33 & 21 & 15 & 19 & 26 & 26 \\
\hline$\%$ mid & 44 & 34 & 54 & 75 & 56 & 53 & 53 \\
\hline$\%$ high & 14 & 33 & 25 & 10 & 25 & 21 & 21 \\
\hline \# of SESSIONS & 31 & 25 & 25 & 28 & 28 & 22 & 159 \\
\hline \multicolumn{8}{|l|}{ Session SIZE } \\
\hline Average & 21 & 20 & 20 & 23 & 22 & 26 & 22 \\
\hline (Min-Max) & $(12-29)$ & $(14-30)$ & $(14-28)$ & $(14-32)$ & $(14-30)$ & $(9-38)$ & $(9-38)$ \\
\hline Std. Dev & 4.12 & 3.48 & 3.48 & 4.59 & 5.61 & 8.38 & 5.46 \\
\hline
\end{tabular}

\footnotetext{
${ }^{10}$ Comparisons across cities of the SEL fractions in each case require caution since each city team used a socioeconomic stratification based on the local methodology for survey stratification samples.
} 
Note the following points: the percentage of females was slightly over $50 \%$, and this was quite stable across the cities. The mean age in our sample was about 37 , and there were more older subjects in Montevideo and more younger individuals in Lima.

On average, the typical participant in our subject pool had 5 years of education (San José has a lower value). As to SEL, one half of the sample were from the middle class, and low class participants were under-represented in Lima and over-represented in Bogotá. Rich people were over-weighted in Buenos Aires but under-weighted in Lima.

Up to the present time, this is the most comprehensive experimental dataset collected in Latin America as regards number of countries, demographics of the sample size and replicability of design in each city.

\subsection{The Strategy Method Ultimatum Game}

During the trust game (activity 1) we can measure how far a player 1 is able to trust another person of similar or different socio-economic characteristics, and whether player 1's actions and characteristics affect player 2's response. Now, with the Strategy Method Ultimatum Game, we seek to measure trust and reciprocity for various degrees of socio-economic level and of social distance between two people who are from the same city but from different social backgrounds.

In our design, each player is given basic information about the player (gender, age, education and SEL) he/she has been paired with, but the players' identities are not revealed. Higher offers by player 1 are interpreted as signals of trust. Reciprocity is interpreted as returns from player 2 that are higher for higher amounts and proportional to the offers from player 1.

The theoretical prediction for this game is that the type-1 player will send a zero offers as he or she cannot be sure that the type- 2 player will return any amount at all. Replications of this game around the world have shown that, on average, players 1 send half their initial endowment to players 2 , and that the returns from player 2 to player 1 generate a net positive return for player 1 of about 10-20\% above what was originally sent.

Subjects were invited to reveal their expectations about first mover actions after they had responded, ${ }^{11}$ that is, they were asked to predict the decisions the other player would make.

11 The role of the impact of expectations on contributions is a research field of increasing interest. There is an extensive discussion about whether beliefs should be elicited before or after subjects choose their strategies (see Kovarik 2008 for a recent review). On the other hand, Dawes et al (1977) showed that people base their expectations on their own past behavior. 
This elicited (hypothetical) expectation indicates each player's level of optimism/pessimism regarding their own payoffs (in the first experimental activity).

\subsection{Empirical strategy}

To capture all the possible motivation positions (from selfishness to generosity) we defined 3 measures to explore reciprocation. These measures were based on the proportion of player 1 investment and the surplus that is returned by player 2 . Note that type- 2 players had to choose from 5 scenarios $(0,25 \%, 50 \%, 75 \%$ or $100 \%$ of the endowment sent by player 1$)$. They were asked to propose 5 "returns" to player 1.

Based on the last four of the proposals mentioned above, ${ }^{12}$ we built 3 indexes (see Box 1 ).

Box 1: Origins of the money and reciprocal behavior

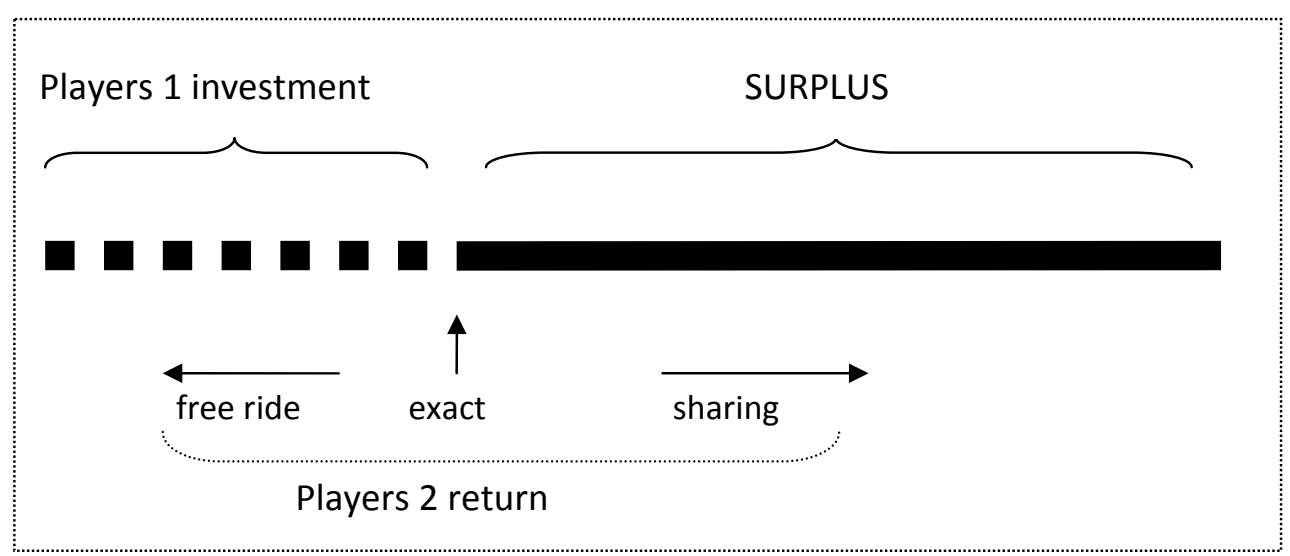

I1 [Free-ride $\left.{ }_{i} \in(0,4)\right]$ is measured as the number of times individual return is less than original player 1 investment

$12\left[\right.$ Exact $\left._{i} \in(0,4)\right]$ is the number of times that player 2 returns player 1 's investment (then player 2 keeps the entire surplus for herself); and,

$13\left[\right.$ Sharing $\left._{i} \in(0,4)\right]$ is the number of times that player 2 shares the surplus with player 1 , that is, he/she returns more money than player 1 invested.

\footnotetext{
${ }^{12}$ The first scenario reflects the case in which player one gives zero to player 2 , so there is neither a surplus nor an investment to return.
} 
Obviously, $11_{i}+12_{i}+13_{i}=4$. The first and the second indexes reflect selfish behavior whereas the last reflects social concern.

Remember that the game was played once, so there was no chance for player 1 to subsequently retaliate against player 2.

In the second part of our analysis we made a more conventional study: we analyzed the determinants of reciprocal behavior in each scenario separately, that is, for $0 \%, 25 \%$ etc., of the endowment.

\subsection{Variables}

As explained above, our dataset was considerably larger than other studies carried out in experimental laboratories. It was also more variable demographically. For example, our subject pool was not restricted to students (of similar ages and family backgrounds) but is more heterogeneous, and we included new variables about subject expectations (block 1). We ordered the variables into three main categories.

(1) The first category reflects a player's expectations about the other players' behavior. Specifically e(money) captures the expectation of player 2 about the amount of money that player 1 will send.

(2) The second block contains Personal Characteristics.

- Gender (Female=1).

- $\quad$ Race $(\text { White=1; Black=1; Indig=1 })^{13}$

- Age (Age and $\left.A g e^{2}\right)$ and,

- Years of Education ${ }^{14}$

\footnotetext{
${ }^{13}$ As regards race, our dataset was composed of white $(56.4 \%)$, indigenous $(2.1 \%)$, mixed race $(39.17 \%)$ and black (2.3\%). Our reference group was always mixed race.

${ }^{14}$ For instance, there are differences in education among cities. The average value in Bogotá is 11.2 years, in Buenos Aires 13.4, in Caracas 12.9, in Lima 12.1, in Montevideo 10.9 and in San José it is 9.9 years.
} 
(3) The third captures an individual's household. First we ascertained whether the subject was Married or Single. ${ }^{15}$ Next, the subject's income was captured in two dimensions: relative wealth $^{16}$ and financial exclusion (Excluded $=1$ if the subject reported himself within this group). Lastly, we labeled subjects who were heads of households as Chief $=1$.

The following section explores the impact of these variables on reciprocal behavior.

\section{3) Results}

Data analysis was divided into two steps. First we studied the determinants of the subject types (free-riding, exact and sharing). Second, we studied the amounts of money returned in three specific scenarios, namely when subjects received the $\min (0 \%)$, the $\max (100 \%)$ and something in between (50\%).

\subsection{Determinants of types}

We now analyzed the above-mentioned measures of reciprocal behavior: free-riding, exact and sharing. First we ran an explorative analysis. Figure 1 shows the histogram for each measure by gender.

The figure on the left is the number of subjects (females or males) that free-ride in the four cases. The first bar illustrates the percentage of males that never free-ride (FREE-0) while the last bar shows what proportion always free-ride (FREE-4).

The figures on the right show gender differences for the "exact" index and the histogram in the center focuses on generous behavior.

This picture yields a result that we will examine in greater detail below, that women are not more generous. It can be seen that a greater percentage of men (as against women) never free-ride, and there are more men than women in the category of those who always share the surplus.

\footnotetext{
${ }^{15}$ The complete distribution of marital status is as follows: unmarried couples (15.9\%), married (28.9\%), widowed (3.5\%), divorced (11.1\%) and single (40.4\%).

${ }^{16}$ This variable captures self-reported level of wealth. Subjects are asked: "Imagine a 10-step ladder in which the poorest households in your city are on step 1 and the wealthiest are on step 10. Where would you position your own household?"
} 
Figure 1: Distribution of types by gender

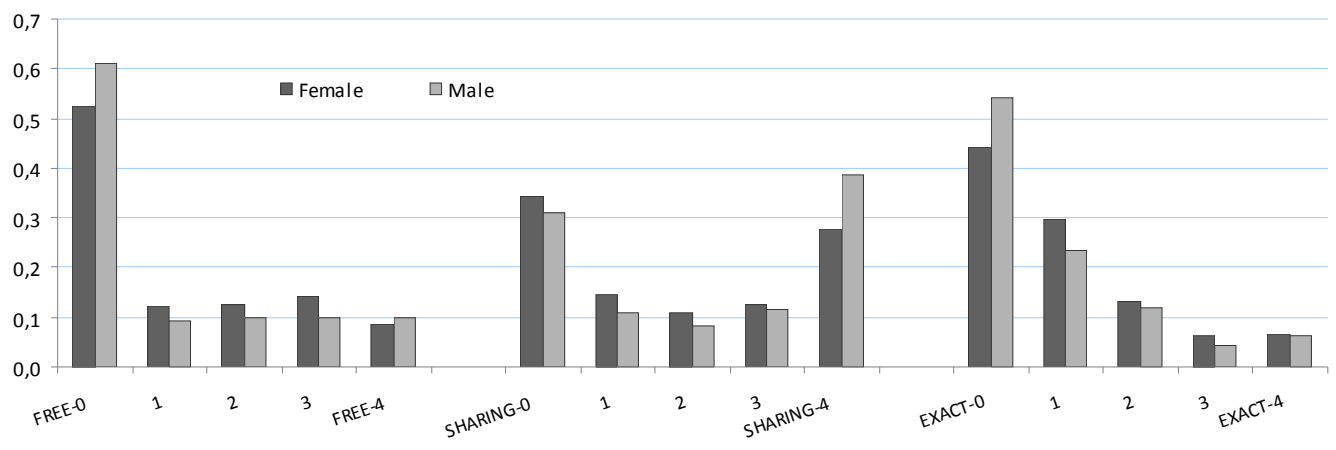

Now we carried out a more detailed examination of behavior. We ran a set of ordered-probit models in which the dependent variable is the number of times an individual exhibits a certain kind of behavior. All the reported results control for the session and the city. ${ }^{17}$ Table 2 shows the results of this estimation. The analysis of these results is carried out by blocks.

As mentioned above, an important result of this study is that, in sharp contrast to previous literature ${ }^{18}$ and in accordance with the recent paper by Cox and Deck (2006), it emerges that women are less generous. Our regressions indicate that females are more inclined to free-ride and less disposed to share the surplus.

Remember that our sessions were organized in line with a stratified sample from the populations of different cities and that our subjects received information about their session mates. Therefore these results indicate that men are more pro-social in this less artefact context. Recall that, in regular lab experiments, women are more pro-social.

According to Levitt and List (2007) an ad-hoc explanation could be women in the lab (but not in the real life) feel more obligated to behave socially than males. This means that women are more sensitive to lab conditions (for instance, "demand effects", low stakes, etc.) and, therefore, they simply appear to be more generous.

\footnotetext{
${ }^{17}$ The regressions we show here do not control by session only for city. When we added the 158 dummies (159 sessions) we did not find significant differences.

${ }^{18}$ See section \#3 of Croson and Gneezy (2006).
} 
Another interesting result is that we found that marital status plays no role. The fact of being married or single seems to be irrelevant in reciprocal behavior. Therefore reciprocity appears to be intrinsic motivation rather than a "shared" value within the household like religosity. ${ }^{19}$

Table 2: Regression analysis

\begin{tabular}{|c|c|c|c|c|c|c|c|c|c|}
\hline & \multicolumn{3}{|c|}{ ALL } & \multicolumn{2}{|c|}{ FREE-RIDING } & \multicolumn{2}{|c|}{ SHARING } & \multicolumn{2}{|c|}{ EXACT } \\
\hline & Free & Sharing & Exact & Female & Male & Female & Male & Female & Male \\
\hline BLOCK 1 & & & & & & & & & \\
\hline e(money) & $\begin{array}{c}-0.000 * \star \star \\
{[0.000]}\end{array}$ & $\begin{array}{c}0.000 * * * \\
{[0.000]}\end{array}$ & $\begin{array}{l}-0.000 * \\
{[0.000]}\end{array}$ & $\begin{array}{c}-0.000 * * \star \\
{[0.000]}\end{array}$ & $\begin{array}{c}-0.000 \text { *** } \\
{[0.000]}\end{array}$ & $\begin{array}{c}0.00{ }^{\star \star \star *} \\
{[0.000]}\end{array}$ & $\begin{array}{c}0.000 * * \star \\
{[0.000]}\end{array}$ & $\begin{array}{l}-0.000 * \\
{[0.000]}\end{array}$ & $\begin{array}{l}-0.000 \\
{[0.000]}\end{array}$ \\
\hline BLOCK 2 & & & & & & & & & \\
\hline female & $\begin{array}{l}0.117^{*} \\
{[0.066]}\end{array}$ & $\begin{array}{c}-0.222^{\star \star \star} \\
{[0.063]}\end{array}$ & $\begin{array}{c}0.202^{\star \star \star} \\
{[0.062]}\end{array}$ & & & & & & \\
\hline white & $\begin{array}{l}0.174^{\star *} \\
{[0.074]}\end{array}$ & $\begin{array}{c}-0.047 \\
{[0.073]}\end{array}$ & $\begin{array}{l}-0.105 \\
{[0.070]}\end{array}$ & $\begin{array}{l}0.174^{*} \\
{[0.098]}\end{array}$ & $\begin{array}{c}0.174 \\
{[0.112]}\end{array}$ & $\begin{array}{c}0.000 \\
{[0.099]}\end{array}$ & $\begin{array}{c}-0.071 \\
{[0.108]}\end{array}$ & $\begin{array}{l}-0.167^{*} \\
{[0.093]}\end{array}$ & $\begin{array}{l}-0.045 \\
{[0.105]}\end{array}$ \\
\hline black & $\begin{array}{c}0.176 \\
{[0.197]}\end{array}$ & $\begin{array}{l}-0.182 \\
{[0.184]}\end{array}$ & $\begin{array}{c}0.102 \\
{[0.171]}\end{array}$ & $\begin{array}{c}0.314 \\
{[0.267]}\end{array}$ & $\begin{array}{c}0.051 \\
{[0.307]}\end{array}$ & $\begin{array}{l}-0.055 \\
{[0.285]}\end{array}$ & $\begin{array}{l}-0.302 \\
{[0.249]}\end{array}$ & $\begin{array}{l}-0.189 \\
{[0.241]}\end{array}$ & $\begin{array}{c}0.344 \\
{[0.246]}\end{array}$ \\
\hline indig & $\begin{array}{c}0.147 \\
{[0.180]}\end{array}$ & $\begin{array}{c}-0.138 \\
{[0.188]}\end{array}$ & $\begin{array}{l}-0.086 \\
{[0.218]}\end{array}$ & $\begin{array}{c}0.347 \\
{[0.245]}\end{array}$ & $\begin{array}{l}-0.008 \\
{[0.259]}\end{array}$ & $\begin{array}{l}-0.326 \\
{[0.215]}\end{array}$ & $\begin{array}{c}0.023 \\
{[0.327]}\end{array}$ & $\begin{array}{c}-0.071 \\
{[0.288]}\end{array}$ & $\begin{array}{l}-0.032 \\
{[0.336]}\end{array}$ \\
\hline age & $\begin{array}{l}-0.016 \\
{[0.013]}\end{array}$ & $\begin{array}{c}0.011 \\
{[0.012]}\end{array}$ & $\begin{array}{l}-0.008 \\
{[0.012]}\end{array}$ & $\begin{array}{c}-0.012 \\
{[0.018]}\end{array}$ & $\begin{array}{l}-0.022 \\
{[0.019]}\end{array}$ & $\begin{array}{l}-0.003 \\
{[0.016]}\end{array}$ & $\begin{array}{c}0.029 \\
{[0.019]}\end{array}$ & $\begin{array}{c}0.011 \\
{[0.017]}\end{array}$ & $\begin{array}{l}-0.028 \\
{[0.019]}\end{array}$ \\
\hline age2 & $\begin{array}{c}0.000 \\
{[0.000]}\end{array}$ & $\begin{array}{l}-0.000 \\
{[0.000]}\end{array}$ & $\begin{array}{c}0.000 \\
{[0.000]}\end{array}$ & $\begin{array}{c}0.000 \\
{[0.000]}\end{array}$ & $\begin{array}{c}0.000 \\
{[0.000]}\end{array}$ & $\begin{array}{c}0.000 \\
{[0.000]}\end{array}$ & $\begin{array}{l}-0.000 \\
{[0.000]}\end{array}$ & $\begin{array}{l}-0.000 \\
{[0.000]}\end{array}$ & $\begin{array}{c}0.000 \\
{[0.000]}\end{array}$ \\
\hline educ & $\begin{array}{c}-0.039 * \star * \\
{[0.010]}\end{array}$ & $\begin{array}{l}0.023^{\star *} \\
{[0.009]}\end{array}$ & $\begin{array}{c}0.011 \\
{[0.009]}\end{array}$ & $\begin{array}{c}-0.037^{\star \star \star} \\
{[0.014]}\end{array}$ & $\begin{array}{c}-0.037^{\star *} \\
{[0.016]}\end{array}$ & $\begin{array}{c}0.015 \\
{[0.013]}\end{array}$ & $\begin{array}{l}0.026^{*} \\
{[0.015]}\end{array}$ & $\begin{array}{l}0.020^{\star} \\
{[0.012]}\end{array}$ & $\begin{array}{l}-0.002 \\
{[0.015]}\end{array}$ \\
\hline
\end{tabular}

\section{BLOCK 3}

\begin{tabular}{rccccccccc} 
married & -0.061 & 0.041 & -0.003 & -0.105 & -0.094 & 0.041 & 0.146 & 0.020 & -0.097 \\
& {$[0.081]$} & {$[0.077]$} & {$[0.078]$} & {$[0.110]$} & {$[0.136]$} & {$[0.104]$} & {$[0.130]$} & {$[0.110]$} & {$[0.129]$} \\
single & -0.065 & 0.020 & 0.026 & -0.169 & 0.135 & 0.137 & -0.195 & -0.010 & 0.108 \\
& {$[0.086]$} & {$[0.082]$} & {$[0.081]$} & {$[0.114]$} & {$[0.141]$} & {$[0.108]$} & {$[0.136]$} & {$[0.104]$} & {$[0.137]$} \\
wealth & $-0.048^{\star *}$ & $0.039^{\star *}$ & -0.015 & -0.043 & $-0.065^{\star \star}$ & 0.035 & $0.052^{*}$ & -0.014 & -0.019 \\
& {$[0.020]$} & {$[0.019]$} & {$[0.018]$} & {$[0.026]$} & {$[0.031]$} & {$[0.025]$} & {$[0.029]$} & {$[0.024]$} & {$[0.027]$} \\
excluded & -0.009 & -0.026 & 0.054 & -0.059 & 0.060 & 0.018 & -0.082 & 0.036 & 0.086 \\
& {$[0.072]$} & {$[0.071]$} & {$[0.071]$} & {$[0.092]$} & {$[0.119]$} & {$[0.090]$} & {$[0.120]$} & {$[0.089]$} & {$[0.119]$} \\
chief & 0.090 & -0.061 & -0.023 & -0.010 & $0.334^{\star *}$ & -0.021 & $-0.299^{* *}$ & 0.010 & 0.061 \\
& {$[0.074]$} & {$[0.069]$} & {$[0.070]$} & {$[0.106]$} & {$[0.133]$} & {$[0.099]$} & {$[0.125]$} & {$[0.104]$} & {$[0.122]$} \\
\hline & & & & & & & & & \\
\hline
\end{tabular}

[Robust standard errors]; * significant at 10\%; ** significant at 5\%; *** significant at $1 \%$

\footnotetext{
${ }^{19}$ For instance, in religious behavior the fact of being married is of key importance (see, among others, BrañasGarza and Neuman, 2007).
} 
Now we explored the determinants of free-riding, sharing and returning the exact investment separately for females and males.

\subsubsection{What explains Free-Riding?}

Player 2's expectation's about the amount of money he/she will receive from player 1 is highly significant. The negative sign of free-riding indicates that individuals who are optimistic about the sender's behavior are less likely to be negatively.

Pessimistic subjects, on the other hand, are disposed to free-ride.

We have seen that women are more inclined to free-ride, and now it emerges that white women are even more selfish. Surprisingly no other races show this tendency and among men we found no race effect.

We did not find any correlation between Age $\left(A g e\right.$ and $\left.A g e^{2}\right)$ and free-riding. The fact that age does not matter in reciprocal behavior is good news for experimental economics since most research is carried out among young subjects (university students).

In sharp contrast, we found a clear effect for Education, which is that better-educated people are less inclined to free-ride. This is true for both females and males. Hence education has a positive effect on the persistence of "pro-social" rules $^{20}$, and consequently erases behavioral patterns that destroy cooperation, such us free-riding.

Self-reported subjective wealth and the responsibilities of heads of households add information for males. Men with lower incomes and greater household responsibilities are more likely to free-ride. Therefore individuals who do not need the money (because they are rich or because they are not the head of the household) are more generous. In other words, those who have "good reasons" to keep the money are more inclined to do so!

\subsubsection{Sharing behavior}

Here again, expectations play a crucial role in behavior. Individuals who were expecting larger amounts of money were more likely to share the (large expected) surplus.

Our results support the view that women are less inclined to share the surplus, but our collection of personal variables does not add any further information on this point. Except for

\footnotetext{
${ }^{20}$ This positive effect is consistent with a previous result shown in Brañas-Garza et al. (forthcoming) for a survey of almost 20,000 Latin Americans. They found that education and several forms of social capital (trust among peers, faith in institutions, etc.) are positively correlated.
} 
expectations, no other single variable is significant for women. We can say very little about the motivation behind women's sharing choices.

For men we find that, once again, education has a significant effect: better-educated males are more likely to share. Self-reported subjective wealth points in the same direction: men with higher incomes are willing to share more. We also find that heads of households are not inclined to share.

Our findings about free-riding show that individuals who "do not need the money" are more willing to share, but this applies only to males. Therefore, responsibility seems to be a crucial determinant in male behavior.

\subsubsection{Returning the exact investment}

The third index captures another sort of behavior: whether player 2 returns the exact amount of money player 1 sent, that is to say whether he/she keeps the entire surplus.

Women are more likely to return the exact investment. This is consistent with the argument from Croson \& Buchan (1999) that women feel extremely obligated "to return at least as much to the proposer as the proposer sent me". Our data showed that this is true and that women were more likely to return the investment, but they kept the surplus.

For women, great expectations (slightly) reduce the probability of this sort of behavior. White women do not use usually return the exact amount of money. Finally, better-educated women are more inclined to behave in this way.

Surprisingly, we found that no single variable (even expectations) is significant for males.

To sum up, from the three cases (free-riding, sharing and returning the exact amount) we may conclude:

- Expectations are crucial: people who are more optimistic are more disposed to share; those who are less optimistic are more disposed to free-ride

- Men are likely to share the surplus and women are inclined to return the investment (but keep the surplus)

- Education enhances pro-social behavior 
- Responsibility makes males less generous

\subsection{Reciprocal Behavior}

In the second part of our analysis we focused on the amount of money type-2 players returned, taking into account the amounts they received. Instead of exploring "types" we directly explore the determinants of reciprocal behavior in each scenario: when player 1 sent the $\min (0 \%)$, the $\max (100 \%)$ and intermediate cases $(25 \%, 50 \%$ and $75 \%)$.

We followed the same strategy as before in that we employed the same collection of independent variables.

Note that when we moved from the first case to the last one $(0 \%, 25 \%, \ldots 100 \%$ tripled), player 2 's pie is clearly bigger. This means that each unit player 2 passes to player 1 gets progressively cheaper (proportionally less costly) as we move from the first scenario to the last.

Andreoni \& Vesterlund (2001) and Cox \& Deck (2006) have studied the cost of generosity and its implications for gender behavior, and they draw conflicting conclusions. The former consider that males are price-elastic (more generous) when altruism is cheap and the latter assume that women are more generous when the cost is reduced, and they state specifically that "Women are more responsive to the costs of generosity whereas the behavior of men can be described as cost-inelastic." (Cox \& Deck 2006: 593)

Secondly, we disaggregated the study for females and males. Table 3 below shows the econometric analysis for the general case $(n=1,548)$ and table 4 shows the relevant regressions only -the min (0), the $\max (12,000)$ and the intermediate cases $(6,000)$ - for females and males separately.

The new analysis yielded results that were consistent with what we found before in that there was a similar gender bias: women are less likely to reciprocate. Two interesting facts are worth noting: i) when player wants passes zero or very little money there is no gender bias; ii) however, in cases in which the generated surplus is high enough, women return less money than men.

This means that when the pie is big enough (and the relative cost of one unit is small) then males are more generous than females. Therefore our results support the findings of Andreoni \& Vesterlund (2001). 
Note that optimism (expected money) always positively affects amounts paid. Individuals who expect more money -females as well as males- return more money to first movers. Therefore expectations play a crucial role in reciprocal behavior.

This "path" is quite similar to our previous results in that women are less disposed to share the surplus. This negative effect among females appears only when the surplus is large enough. We will see below in table 4 that education definitively conditions behavior. Better educational levels make for increased positive reciprocity. In this, two important points should be noted: first, we find that education is not correlated to gender, and second, the negative sign for the first scenario shows that better-educated subjects punish selfish players (who sent nothing) whereas the positive sign in the high value levels $(75 \%$ or $100 \%)$ indicates that better-educated individuals reward generous subjects. We can conclude that education triggers social rules and makes subjects aware of anti-social behavior.

Other effects such as race, age or earnings will vary when the analysis is repeated for females or males only. We found strong gender effects for these variables.

\subsubsection{Giving for nothing $(0 \% \times 3)$}

The first case explores the situation in which subjects were asked to return money when in fact they had not received a single dollar. Type-2 players were therefore giving away part of their own endowment. Note that we do not know if subjects returned less money because they had strong convictions about fairness or just because they were selfish.

We consider that education makes people aware of selfish behavior, and it would be consistent to suppose that better-educated subjects are unwilling to pass money to type-1 players who previously passed zero. We found this negative effect for both women and men. Alternatively we might take the view that education increases selfishness, but when we checked we found that this educational effect is completely consistent with that we saw previously, namely that education enhances pro-social values and destroy anti-social patterns. Consequently, better-educated subjects punish selfish behavior (sending 0 ).

In addition, we found that indigenous and financially excluded subjects are less likely to return any money at all when player 1 did not pass any money.

It can be seen in table 4 that the indigenous and the exclusion effects were both more marked among women than among men. For males, we found an identical negative effect for single men: they are less disposed to reciprocate. 
Table 3: Regression analysis

MONEY RECEIVED BY PLAYER 2

\begin{tabular}{|c|c|c|c|c|c|}
\hline & Min: 0\% & $25 \% \times 3$ & $50 \% \times 3$ & $75 \% \times 3$ & Max:100\%x3 \\
\hline \multicolumn{6}{|l|}{ BLOCK 1} \\
\hline e(money) & $\begin{array}{c}0.000 * \star \star \\
{[0.000]}\end{array}$ & $\begin{array}{c}0.000 * * * \\
{[0.000]}\end{array}$ & $\begin{array}{c}0.000 * \star \star \\
{[0.000]}\end{array}$ & $\begin{array}{c}0.000 * * * \\
{[0.000]}\end{array}$ & $\begin{array}{c}0.000 * * * \\
{[0.000]}\end{array}$ \\
\hline \multicolumn{6}{|l|}{ BLOCK 2} \\
\hline female & $\begin{array}{c}0.005 \\
{[0.064]}\end{array}$ & $\begin{array}{l}-0.085 \\
{[0.059]}\end{array}$ & $\begin{array}{c}-0.160 * * * \\
{[0.057]}\end{array}$ & $\begin{array}{c}-0.185^{\star \star *} \\
{[0.056]}\end{array}$ & $\begin{array}{c}-0.122^{\star \star} \\
{[0.057]}\end{array}$ \\
\hline white & $\begin{array}{l}-0.072 \\
{[0.071]}\end{array}$ & $\begin{array}{l}-0.066 \\
{[0.067]}\end{array}$ & $\begin{array}{l}-0.120 * \\
{[0.066]}\end{array}$ & $\begin{array}{c}-0.134^{\star \star} \\
{[0.065]}\end{array}$ & $\begin{array}{l}-0.117^{*} \\
{[0.065]}\end{array}$ \\
\hline black & $\begin{array}{c}0.083 \\
{[0.210]}\end{array}$ & $\begin{array}{l}-0.278 \\
{[0.209]}\end{array}$ & $\begin{array}{c}-0.167 \\
{[0.211]}\end{array}$ & $\begin{array}{l}-0.237 \\
{[0.152]}\end{array}$ & $\begin{array}{c}-0.189 \\
{[0.186]}\end{array}$ \\
\hline indig & $\begin{array}{l}-0.318^{*} \\
{[0.192]}\end{array}$ & $\begin{array}{l}-0.124 \\
{[0.197]}\end{array}$ & $\begin{array}{c}-0.073 \\
{[0.190]}\end{array}$ & $\begin{array}{c}-0.030 \\
{[0.192]}\end{array}$ & $\begin{array}{l}-0.291^{*} \\
{[0.174]}\end{array}$ \\
\hline age & $\begin{array}{c}0.023^{*} \\
{[0.013]}\end{array}$ & $\begin{array}{l}0.023^{*} \\
{[0.012]}\end{array}$ & $\begin{array}{c}0.011 \\
{[0.011]}\end{array}$ & $\begin{array}{c}0.019 * \\
{[0.011]}\end{array}$ & $\begin{array}{c}0.017 \\
{[0.012]}\end{array}$ \\
\hline age2 & $\begin{array}{l}-0.000 \\
{[0.000]}\end{array}$ & $\begin{array}{l}-0.000 \\
{[0.000]}\end{array}$ & $\begin{array}{c}-0.000 \\
{[0.000]}\end{array}$ & $\begin{array}{l}-0.000 \\
{[0.000]}\end{array}$ & $\begin{array}{l}-0.000 \\
{[0.000]}\end{array}$ \\
\hline educ & $\begin{array}{c}-0.049 * \star \star \\
{[0.010]}\end{array}$ & $\begin{array}{l}-0.000 \\
{[0.009]}\end{array}$ & $\begin{array}{c}0.013 \\
{[0.009]}\end{array}$ & $\begin{array}{c}0.025^{\star \star \star} \\
{[0.009]}\end{array}$ & $\begin{array}{c}0.026 * \star \star \\
{[0.009]}\end{array}$ \\
\hline \multicolumn{6}{|l|}{ BLOCK 3} \\
\hline married & $\begin{array}{c}0.077 \\
{[0.077]}\end{array}$ & $\begin{array}{c}0.016 \\
{[0.074]}\end{array}$ & $\begin{array}{c}0.084 \\
{[0.072]}\end{array}$ & $\begin{array}{c}0.040 \\
{[0.072]}\end{array}$ & $\begin{array}{c}0.060 \\
{[0.070]}\end{array}$ \\
\hline single & $\begin{array}{l}-0.015 \\
{[0.083]}\end{array}$ & $\begin{array}{c}-0.002 \\
{[0.078]}\end{array}$ & $\begin{array}{c}0.045 \\
{[0.078]}\end{array}$ & $\begin{array}{c}0.048 \\
{[0.077]}\end{array}$ & $\begin{array}{c}0.099 \\
{[0.077]}\end{array}$ \\
\hline wealth & $\begin{array}{c}0.015 \\
{[0.020]}\end{array}$ & $\begin{array}{l}-0.008 \\
{[0.019]}\end{array}$ & $\begin{array}{l}0.046^{\star *} \\
{[0.019]}\end{array}$ & $\begin{array}{l}0.042^{\star *} \\
{[0.018]}\end{array}$ & $\begin{array}{c}0.050 * \star * \\
{[0.018]}\end{array}$ \\
\hline excluded & $\begin{array}{c}-0.172^{\star \star} \\
{[0.074]}\end{array}$ & $\begin{array}{c}0.014 \\
{[0.069]}\end{array}$ & $\begin{array}{c}0.025 \\
{[0.068]}\end{array}$ & $\begin{array}{c}-0.071 \\
{[0.065]}\end{array}$ & $\begin{array}{c}-0.041 \\
{[0.066]}\end{array}$ \\
\hline chief & $\begin{array}{c}0.006 \\
{[0.074]}\end{array}$ & $\begin{array}{c}-0.083 \\
{[0.067]}\end{array}$ & $\begin{array}{c}-0.106 \\
{[0.066]}\end{array}$ & $\begin{array}{c}-0.100 \\
{[0.066]}\end{array}$ & $\begin{array}{c}-0.035 \\
{[0.065]}\end{array}$ \\
\hline $\begin{array}{c}\text { Observations } \\
\text { Pseudo R2 }\end{array}$ & $\begin{array}{c}1548 \\
0.08 \\
\end{array}$ & $\begin{array}{l}1549 \\
0.06\end{array}$ & $\begin{array}{c}1548 \\
0.05 \\
\end{array}$ & $\begin{array}{c}1548 \\
0.05 \\
\end{array}$ & $\begin{array}{c}1548 \\
0.04 \\
\end{array}$ \\
\hline
\end{tabular}

\subsubsection{Sharing when rich $(100 \% \times 3)$}

The second case shows the opposite situation: subjects were asked to return money when they had received a substantial amount of money due to player 1 trust. In this case, type-2 players had made a lot of money and therefore might behave generously because players 1 had previously been generous. 
Our findings were consistent with what we saw in the previous case, that education promotes social behavior. In this case, when subjects had received a large amount of money, bettereducated individuals returned more money, which is positive reciprocity. Table 4 shows that the educational effect among men is similar to that among women.

Table 4: Regression analysis by gender

\begin{tabular}{|c|c|c|c|c|c|c|}
\hline & \multicolumn{6}{|c|}{ Money Received by Player 2} \\
\hline & \multicolumn{2}{|c|}{ Min: $0 \%$} & \multicolumn{2}{|c|}{ Between: 50\%x3 } & \multicolumn{2}{|c|}{ Max: $100 \% x 3$} \\
\hline & Female & Male & Female & Male & Female & Male \\
\hline BLOCK 1 & & & & & & \\
\hline e(money) & $\begin{array}{c}0.000^{\star * *} \\
{[0.000]}\end{array}$ & $\begin{array}{c}0.000^{\star \star *} \\
{[0.000]}\end{array}$ & $\begin{array}{c}0.000^{\star * *} \\
{[0.000]}\end{array}$ & $\begin{array}{c}0.000 \star \star \star \\
{[0.000]}\end{array}$ & $\begin{array}{c}0.000^{\star * *} \\
{[0.000]}\end{array}$ & $\begin{array}{c}0.000 * * * \\
{[0.000]}\end{array}$ \\
\hline \multicolumn{7}{|l|}{ BLOCK 2} \\
\hline white & $\begin{array}{c}-0.111 \\
{[0.100]}\end{array}$ & $\begin{array}{l}-0.016 \\
{[0.104]}\end{array}$ & $\begin{array}{c}-0.092 \\
{[0.091]}\end{array}$ & $\begin{array}{c}-0.152 \\
{[0.097]}\end{array}$ & $\begin{array}{c}-0.053 \\
{[0.090]}\end{array}$ & $\begin{array}{l}-0.176^{*} \\
{[0.094]}\end{array}$ \\
\hline black & $\begin{array}{c}0.175 \\
{[0.292]}\end{array}$ & $\begin{array}{l}-0.055 \\
{[0.313]}\end{array}$ & $\begin{array}{c}-0.039 \\
{[0.339]}\end{array}$ & $\begin{array}{l}-0.349 \\
{[0.266]}\end{array}$ & $\begin{array}{l}-0.180 \\
{[0.295]}\end{array}$ & $\begin{array}{c}-0.254 \\
{[0.243]}\end{array}$ \\
\hline indig & $\begin{array}{l}-0.490^{\star} \\
{[0.272]}\end{array}$ & $\begin{array}{c}-0.127 \\
{[0.252]}\end{array}$ & $\begin{array}{c}-0.231 \\
{[0.244]}\end{array}$ & $\begin{array}{c}0.080 \\
{[0.288]}\end{array}$ & $\begin{array}{c}-0.443^{\star *} \\
{[0.226]}\end{array}$ & $\begin{array}{c}-0.117 \\
{[0.269]}\end{array}$ \\
\hline age & $\begin{array}{c}0.025 \\
{[0.019]}\end{array}$ & $\begin{array}{c}0.024 \\
{[0.019]}\end{array}$ & $\begin{array}{c}-0.006 \\
{[0.016]}\end{array}$ & $\begin{array}{c}0.033^{*} \\
{[0.017]}\end{array}$ & $\begin{array}{c}0.010 \\
{[0.017]}\end{array}$ & $\begin{array}{c}0.024 \\
{[0.017]}\end{array}$ \\
\hline age2 & $\begin{array}{l}-0.000 \\
{[0.000]}\end{array}$ & $\begin{array}{c}-0.000 \\
{[0.000]}\end{array}$ & $\begin{array}{c}0.000 \\
{[0.000]}\end{array}$ & $\begin{array}{l}-0.000 * \\
{[0.000]}\end{array}$ & $\begin{array}{l}-0.000 \\
{[0.000]}\end{array}$ & $\begin{array}{l}-0.000 \\
{[0.000]}\end{array}$ \\
\hline educ & $\begin{array}{c}-0.050 \star \star \star \\
{[0.013]}\end{array}$ & $\begin{array}{c}-0.049 * * * \\
{[0.015]}\end{array}$ & $\begin{array}{c}0.006 \\
{[0.012]}\end{array}$ & $\begin{array}{c}0.018 \\
{[0.014]}\end{array}$ & $\begin{array}{c}0.023^{*} \\
{[0.012]}\end{array}$ & $\begin{array}{l}0.028 * * \\
{[0.013]}\end{array}$ \\
\hline \multicolumn{7}{|l|}{ BLOCK 3} \\
\hline married & $\begin{array}{c}0.110 \\
{[0.111]}\end{array}$ & $\begin{array}{c}0.053 \\
{[0.123]}\end{array}$ & $\begin{array}{c}0.158 \\
{[0.099]}\end{array}$ & $\begin{array}{c}0.086 \\
{[0.117]}\end{array}$ & $\begin{array}{c}0.081 \\
{[0.097]}\end{array}$ & $\begin{array}{c}0.119 \\
{[0.114]}\end{array}$ \\
\hline single & $\begin{array}{c}0.163 \\
{[0.111]}\end{array}$ & $\begin{array}{c}-0.266^{\star \star} \\
{[0.130]}\end{array}$ & $\begin{array}{l}0.240 * * \\
{[0.104]}\end{array}$ & $\begin{array}{c}-0.299 \star \star \\
{[0.125]}\end{array}$ & $\begin{array}{c}0.193^{*} \\
{[0.103]}\end{array}$ & $\begin{array}{l}-0.090 \\
{[0.122]}\end{array}$ \\
\hline earnings & $\begin{array}{c}0.032 \\
{[0.026]}\end{array}$ & $\begin{array}{c}-0.001 \\
{[0.030]}\end{array}$ & $\begin{array}{l}0.056^{\star *} \\
{[0.025]}\end{array}$ & $\begin{array}{c}0.043 \\
{[0.029]}\end{array}$ & $\begin{array}{c}0.067^{\star \star \star} \\
{[0.024]}\end{array}$ & $\begin{array}{c}0.034 \\
{[0.028]}\end{array}$ \\
\hline excluded & $\begin{array}{c}-0.198 * \star \\
{[0.095]}\end{array}$ & $\begin{array}{c}-0.145 \\
{[0.123]}\end{array}$ & $\begin{array}{c}0.058 \\
{[0.085]}\end{array}$ & $\begin{array}{c}0.002 \\
{[0.113]}\end{array}$ & $\begin{array}{c}-0.039 \\
{[0.085]}\end{array}$ & $\begin{array}{c}-0.033 \\
{[0.106]}\end{array}$ \\
\hline chief & $\begin{array}{c}-0.004 \\
{[0.115]}\end{array}$ & $\begin{array}{c}-0.072 \\
{[0.120]}\end{array}$ & $\begin{array}{c}-0.058 \\
{[0.097]} \\
\end{array}$ & $\begin{array}{c}-0.374^{\star \star \star} \\
{[0.112]}\end{array}$ & $\begin{array}{c}0.033 \\
{[0.096]}\end{array}$ & $\begin{array}{c}-0.237^{\star *} \\
{[0.113]}\end{array}$ \\
\hline $\mathrm{N}$ & 849 & 699 & 849 & 699 & 849 & 699 \\
\hline Pseudo R2 & 0.10 & 0.07 & 0.06 & 0.05 & 0.05 & 0.04 \\
\hline
\end{tabular}

We can also see in table 3 that white and indigenous subjects are less likely to reciprocate in response to player 1 generosity. Interestingly, table 4 reveals part of the effect since we can 
see that indigenous women (but not men) are less inclined to reciprocate. We also found that white men (but not women) do not share the money.

Table 3 shows that richer people share a higher proportion of the surplus with player 1 . We can see in table 4 that this effect was more common among women than among men. We also found that single women are more willing to return a greater amount of money. One possible explanation could be that they have fewer financial responsibilities.

In the case of males, again we see the effect of responsibilities since individuals who are heads of households return less of the surplus.

\subsubsection{The intermediate cases $(25 \% \times 3,50 \% \times 3$ and $75 \% \times 3)$}

We now focus on the last case: subjects receive a positive gift but not the maximum. This means that type-2 players made some money due to player 1 generosity (but not the maximum) and thus had the chance to return some fraction of this money to player 1 .

In general, we found some positive effects for age and income (table 3), but on the other hand we found a negative effect for being white rather than of some other race.

A more detailed analysis in table 4 reveals that women show more or less the same effects as before, that is to say they are more inclined to reciprocal behavior if they are single and rich.

For males we found some variations. Age (and age ${ }^{2}$ ) shows a concave path, which means that reciprocity increases (at a decreasing rate) with age, single men are more selfish, and once again responsibility negatively affects reciprocal behavior.

To sum up, from the five cases $(0 \% \ldots 100 \% \times 3)$ we may conclude:

- As Andreoni \& Vesterlund (2001) maintain, gender bias appears -in favor of more generous men- for larger pie sizes $(6,000,9,000$ and 12,000$)$, that is when monetary costs are proportionally cheaper.

- Expectations are crucial: individuals who are more optimistic return more money.

- Education plays a determinant role in reciprocal behavior: better education makes subjects return very little (much) when they receive very little (much) of the pie. In addition, better education prompts people to punish anti-social behaviors.

- The fact of being single seems to be relevant but the effect for women is different from that for men in that females are more generous and males more selfish. 
- Responsibility has an effect for males: men who support a family are less generous.

\section{4) Discussion: Why did previous studies yield different results?}

Our study yielded an "unexpected" result since it emerged that women are not more generous than men. This finding basically contradicts the findings of most previous studies, so we asked ourselves why previous papers reported quite different results. Basically there are three possibilities: 1) Latin-American people are different; 2) previous papers were based on datasets that were too small; 3) Women are more generous in the lab but not in the field.

Unfortunately we could investigate the first of these possibilities as we do not have a comparable dataset for northern countries, but we were able to use our dataset to check the second possibility. We employed a double strategy based on the composition of the sample.

- We repeated the entire analysis but limited the sample to subjects with at least 12 years of education, that is to individuals who had completed at least the first year of undergraduate studies. This strategy meant we were able to replicate the standard university subject pool of previous experiments and to introduce age (and $a g e^{2}$ ) to allow us to control other effects. The money return analysis for the six cases (free, sharing, exact, $0 \times 3,6,000 \times 3$ and $12,000 \times 3$ ) is given in table $A 1$ in the appendix.

- Secondly, we restricted the subject pool by age in that we specifically explored subjects only during their university years $(17<y e a r s<25)$. The use of other variables as controls enabled us to explore co-founding effects. Table A2 in the appendix shows the money return analysis for the six cases.

The analysis of types carried out with the sample of "educated" people is shown in the left part of table A1. The replication for the reduced sample yields a surprising result, which is that women are not more disposed to free-ride. Men are more willing to share the surplus but women tend to return the complete investment to player 1.

This result is confirmed in the second part of the analysis shown in table A1. When we explored the return ratio for each scenario $(0 \times 3,6,000 \times 3$ and $12,000 \times 3)$ we found that gender bias vanishes! Only a weak effect is found for the intermediate case.

Another significant result is that white and indigenous individuals are both much more inclined to hold attitudes that negate cooperation like free-riding and small return ratios. Also note that education is no longer significant once the subject reaches the university educational level. 
The second line of the analysis was carried out for a subject pool of individuals of 18-24 years old, that is to say a typical experiment sample. Table A2 in the appendix shows this replication. Surprisingly we found that the female coefficient is never significant, and in a number of cases

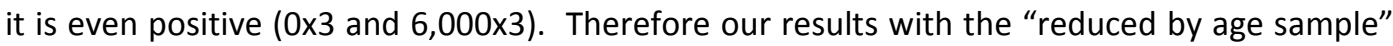
do not really contradict those reported in previous papers.

Even in this small sample we again find that education is a key factor in the emergence of prosocial behavior. Better-educated people are less inclined to free-ride, more willing to share, and more disposed to punish people who sent very little money $(0 \times 3)$. All things considered, the role of expectation is also crucial. Optimistic individuals share more and are less likely to free-ride.

What can we say about the differences between our findings and those of previous papers? Our replications give a simple explanation for the contradiction between our results and the gender effects reported in previous studies, and it is that the datasets employed in those studies were insufficient to provide definitive conclusions. Tables A1 and A2 show that no gender bias emerges when the sample is reduced to subjects who are "young" or have a university degree. This is precisely the type of individuals who participate in most lab experiments.

It is vitally important to bear in mind that even in this reduced sample we have 625 individuals (table A1) or 374 subjects (table A2). Therefore our "enormous" dataset of typical participants in experiment sessions shows that no gender bias is systematically found. Obviously a random "extraction" of 50 or 60 individuals could indicate that women are more generous than men, or that there are more selfish females. We will now explore this case.

Using the sample of $18-24$ year-old subjects $(N=374)$ we made 250 random draws of subsamples of 100 individuals. For each sub-sample we repeated the three main money return scenarios (free, sharing and exact). Therefore we counted 250x3 money return scenarios.

These money return scenarios are summarized in table 5 . We only report the number of cases where gender is significant, for each case, for sub-samples of 18-24 year-old subjects.

The first result is that gender does not play a significant role in free-riding in $90 \%$ of the cases. In $8.2 \%$ young women are more disposed to free-ride, and only in $1.8 \%$ of the cases young women are more generous. 
Table 5: Random replications

\begin{tabular}{ccccccc} 
& Free & {$[\%]$} & Sharing & {$[\%]$} & Exact & {$[\%]$} \\
\hline Significant cases & 24 & & 32 & & 29 & \\
\hline Female $>0$ & 21 & {$[8.4]$} & 4 & {$[1.6]$} & 20 & {$[8.0]$} \\
Female $<0$ & 3 & {$[1.2]$} & 28 & {$[11.2]$} & 9 & {$[3.6]$} \\
\hline Non-significant cases & 226 & {$[90.4]$} & 218 & {$[87.2]$} & 221 & {$[88.4]$} \\
\# regressions & 250 & & 250 & & 250 & \\
\hline
\end{tabular}

In the "sharing" category there is a high percentage (87.2\%) of cases in which gender is not significant. Remember that the sample consists of young subjects. In $11 \%$ of the money return scenarios women are less likely to share, and in only $1.6 \%$ of them women are more generous.

Returning the full investment but no more is also gender-free in $88 \%$ of the repetitions. In some cases (8\%), women are more inclined to return the investment, and in only $3.6 \%$ of the cases men are more willing to repay player 1's investment completely.

To sum up, when reduced subject pools -including only typical university students- are used, it is not possible to draw definitive conclusions about gender differences. In fact, recursive repetitions of the money return analysis using random draws makes it possible to conclude that larger samples are necessary for precise studies of socio-demographic features.

Finally we should consider additional effects caused by the field (vs the lab). According to Levitt and List (2007) there are a number of issues affecting lab experiments:

i) The subject pool. Usually they are university student who respond to voluntary calls (self-selection of individuals). In our experiment subjects were recruited in the streets. Moreover, the salient heterogeneity among participants may have a direct effect on participants: they would find difficulties in guessing their partner's behavior ( $1^{\text {st }}$ and $2^{\text {nd }}$ order beliefs) given that all of them are "real" strangers.

ii) Additionally, we also have strong differences regarding procedures: we did not use computerized rooms (neither PC's), we have monitors explaining the complete procedures (and assisting people with very low education level), we use paper \& pencil, etc.

Obviously women (or men) may react differently to i) and ii) or both. 
We do consider that our experimental conditions are the appropriate to study how ordinary people behave. Our intention was to capture how the daily context of the participants and their interaction with other citizens of the same city but ultimately with different backgrounds affected their propensity to trust and their trustworthiness

\section{5) Conclusions}

In this study we used data from a field experiment conducted under identical conditions (and with identical monetary payoffs) in 6 Latin American cities. Our dataset amounted to 3,107 experimental subjects. Despite its size, our experiment was designed to control by age, social groups, gender composition and so on. Therefore our dataset was large and heterogeneous enough to provide a meaningful analysis.

Our study of reciprocal behavior in this paper adds to the literature in a number of ways.

1) The role of beliefs in reciprocal behavior. We consistently found that optimism is positively correlated to sharing and negatively to free-riding. Therefore optimism enhances reciprocity.

In the study of types, we saw that those who returned a larger fraction of the pie also considered that first movers were themselves cooperating agents. In other words, those who did not cooperate were not expecting any positive return. In the analysis of reciprocal behavior we found that expectations have a systematic positive effect. The fact that these results both occurred may be indicative of conditional cooperation: those who expected good behavior behaved kindly to previous players (see Keser and van Winden, 2000).

2) We showed that women are more selfish than men when it comes to sharing a surplus, but fairer when paying back an initial investment.

Our results indicate that women are more (less) disposed to free-ride (share). The use of a third index (paying back) provides a more complete explanation: women are more likely to fully return the player 1 investment, but they feel more entitled to keep the surplus for themselves. Therefore they are behaving selfishly but they are not cheating. In addition we show that gender bias emerges when the pie is big enough.

At this point we would like to stress that we employed a large number of observations and examined a wide variety of personal features among our experiment subjects. These subjects 
were not students interacting with students, they were ordinary people interacting with anonymous fellow citizens. Therefore we may conclude that our subject pool faced a less artefactual situation.

When we compare our results with those of previous papers we may conclude the following. According to Croson \& Buchan (1999), women "paid back" more than men (probably because they felt guilty), but in contrast to this finding and to Chaudhuri and Gangadharan (2003), we did not find women to be more generous. We agree with Cox (2002) when we find that men are more generous than women, but in contrast to Cox and Deck (2006) we did not find that women are more generous when the cost of giving is reduced. Therefore our findings are consistent with Andreoni and Vesterlund (2001).

Moreover, in a recent study, D'Exelle (2008) reported a similar conclusion, that males are more generous. He conducted a dictator game with 123 households in one village in Nicaragua and found that female dictators sent lower offers than males.

This contrasts with previous lab dictator game experiments (...) that demonstrated that female dictators are more generous than male dictators. Young female students in Northern universities, however, can hardly be compared with poor women who are struggling to cope with everyday responsibilities such as child health and education. In particular, a plausible explanation for this difference can be found in studies on gender differences regarding income spending in poor countries. D'Exelle (2008: 104)

We repeated the main econometric analysis of the our paper using a reduced sample of only typical university students. Our main conclusion is that gender does not appear to be significant. In addition, we made recursive repetitions of the analysis using random draws and we showed that in very few cases women behave differently from men. Therefore, even assuming that Latin American people might be different, we conclude that in previous studies the datasets were too small.

3) We found that selfish and generous behavior in females and males is motivated by different reasons.

Our paper yields a number of results in which the forces driving decisions for females are not the same than those of males. The most outstanding case is responsibility for males: the fact that a man is a household head has a significant effect but this never appears as a significant factor for women. Aguiar et al. (2008) shows that dictatorial allocations are crucially affected 
by moral reasons: when subjects consider that they do have a better alternative use for the money (than the recipient payoff) then they do not pass any amount of money, but on the other hand if they do not need the money then they transfer the whole endowment. Our paper shows this effect for males.

D'Exelle (2008) argues that women in underdeveloped countries are not generous (in contrast to northern females) because they are in charge of the family, that is, they have heavy responsibilities. However, this is not what we found in our data since women who are single (and supposedly without children) are more likely to share the surplus. In addition, we saw that the household dummy is significant for men but not for women.

As we saw in section 4 above, no single result emerged as regards gender bias in generosity because of data limitation (sample size). Obviously other cultural differences, for instance differences in money managing ${ }^{21}$, might also cause a gender bias. For example, our data showed that marital status, if it matters, affects women in the opposite direction that it affects men. Single women tend to be more generous but the same figure for males enhances selfishness.

Therefore we conclude that the reasons driving this behavior are substantially different. This is consistent with recent studies which claim that the magnitude and the direction of gender differences are far from being explained (see Cox and Deck (2006), Croson and Gneezy (2006), Leon-Mejia and Miller (2007)). Hence we do not just conclude that there are gender differences in terms of observed generosity, we have also shown that the causality is different as well.

Our study has an interesting policy implication. The way in which women and men differ in terms of reciprocal altruism is not trivial since women feel entitled to keep a surplus but men are more inclined to share it. If any multilateral institution or aid agency runs programs (e.g. the transfer of subsidies to families) we predict that that men will share the surplus with other members of society whereas women will keep the "fair" money for themselves and their families. This was what happened in some successful transfer programs such as "Progresa" in Mexico and "Familias en Acción" in Colombia.

\footnotetext{
${ }^{21}$ See D'Exelle (2008) and other references cited in.
} 
On the other hand, when the payment is made not to a family but to set up a business, we believe that a woman will spend the money properly whereas ${ }^{22}$ a man will share part of the money with other individuals who are also in need financial assistance.

4) Individual level of education enhances reciprocal behavior. Better-educated subjects are kinder to people who were kind first. In addition, we found that better-educated subjects punish selfish behavior more. There was no gender bias in these findings.

This is a very interesting result. We were able to capture this effect because our sample was much more demographically varied than the usual student sample in lab experiments.

The positive influence of education on economic development is well known. Education increases labor productivity and therefore enhances competitiveness, $R+D$ returns, etc.

Some recent empirical studies have found a different source for economic development, the positive effect of social capital on economic performance and growth (see Guiso et al. 2002, Zak and Knack 2001). If a society is organized in accordance with good rules, this facilitates market exchanges and reduces transaction costs, so social capital promotes economic development.

Our results connect both ideas. In this paper we show that education enhances the promotion of social values (and the erosion of anti-social behaviors) and subsequently-following the Zak and Knack (2001) path ${ }^{23}$ - it fosters an environment that promotes economic development.

\footnotetext{
${ }^{22}$ Hoddinott \& Haddad (1995) showed in Cote d'Ivoire that the share of income controlled by women is positively correlated with food shares.

${ }^{23}$ Zak and Knack (2001) argue that interpersonal trust has a substantial positive impact on economic growth, and that some degree of interpersonal trust is necessary for economic development.
} 


\section{References}

- F. Aguiar, P. Brañas-Garza and L. Miller. 2008. "Moral distance in Dictator Games," Judgment and Decision Making 3(4): 344-354.

- F. Aguiar, P. Brañas-Garza, R. Cobo-Reyes, N. Jiménez and L. Miller. Forthcoming. "Are women expected to be more generous?" Experimental Economics.

- J. Andreoni and L. Vesterlung. 2001. "Which Is the Fair Sex? Gender Differences in Altruism," Quarterly Journal of Economics 116(1): 293-312.

- A. Barr and P. Sierneels. Forthcoming. "Reciprocity in the workplace," Experimental Economics.

- B. J. Dickhaut and K. McCabe. 1995. "Trust, reciprocity and social history," Games and Economic Behavior 10: 122-142.

- P. Brañas-Garza, M. Rossi and D. Zaclicever. Forthcoming. "Individual's Religiosity Enhances Trust: Latin American Evidence for the Puzzle," Journal of Money, Credit and Banking.

- P. Brañas-Garza and S. Neuman. 2007. "Parental Religiosity and Daughters' Fertility: The Case of Catholics in Southern Europe," Review of Economics of the Household 5(3):305-327.

- N. Candelo and S. Polonia .2007. "Pasos metodológicos de un diseño experimental para medir capital social y acción colectiva en seis ciudades latinoamericanas". Mimeo. Universidad de Los Andes, Bogotá.

- J.C. Cárdenas, A. Chong and H. Ñopo. 2008. "Stated Social Behavior and Revealed Actions: Evidence from Six Latin American Countries Using Representative Samples," Universidad de los Andes mimeo.

- J. Carpenter, G. Harrison and J. List, eds. (2005), "Field Experiments in Economics" (Greenwich, CT: JAI Press, Research in Experimental Economics, Volume 10).

- A. Chaudhuri and L. Gagadharan. 2003. "Gender Differences in Trust and Reciprocity," Working Paper, University of Auckland mimeo.

- J. C. Cox. 2002. "Trust, Reciprocity, and Other-Regarding Preferences: Groups vs. Individuals and Males vs. Females," in Rami Zwick and Amnon Rapoport (eds.) Experimental Business Research: 331- 350 Boston: Kluwer Academic Publishers.

- J. C. Cox and C. A. Deck. 2006. "When Are Women More Generous than Men?," Economic Inquiry 44: 587-598.

- R. Croson and N. Buchan. 1999. "Gender and Culture: International Experimental Evidence from Trust Games," American Economic Review 89(2): 386-391.

- R. Croson and U. Gneezy. 2006. "Gender Differences in Preferences," The Wharton School mimeo.

- B. D'Exelle. 2008. "Inequality, Networks and Exclusion: Distributive Decision-making in Small-Scale Societies," Doctoral Dissertation, Maastricht University, The Netherlands.

- R. M. Dawes, J. McTavish and H. Shaklee. 2008. "Behavior, communication, and assumptions about other people's behavior in a commons dilemma situation," Journal of Personality and Social Psychology 35(1):1-11. 
- C. C. Eckel and P. J. Grossman. 2006. "Men, women and risk aversion: experimental evidence," Virginia Tech mimeo.

- L. Guiso, P. Sapieza and L. Zingales. 2002. "People's opium? Religion and economic attitudes," Journal of Monetary Economics 50: 225-282.

- J. Hoddinott and L. Haddad. 1995. "Does Female Income Share Influence Household Expenditures? Evidence from Cote d'Ivoire," Oxford Bulletin of Economics and Statistics 57(1):77-96.

- G. W. Harrison and J. A. List (2004) "Field Experiments". Journal of Economic Literature XLII: 1009-1055.

- IADB.2008. S. Calónico, N. Candelo, J.C. Cárdenas, A. Chong, H. Noopo and S. Polanía. "To What Extent Do Latin Americans Trust and Cooperate? Field Experiments on Social Exclusion in Six Latin American Countries". Chapter 7 in IADB "Outsiders? The Changing Patterns of Exclusion in Latin America and the Caribbean". IADB and DRCLAS Harvard.

- C Keser, and Franz Van Winden. 2000. "Conditional Cooperation and Voluntary Contributions to Public Goods", Scandinavian Journal of Economics 102(1): 23-29.

- J. Kovarik. 2008. "Belief Formation and Evolution in Public Good Games," Universidad de Alicante mimeo.

- A. Leon-Mejia and L. Miller. 2007. "The Devil is in the Details - Sex Differences in Simple Bargaining Games," Jena Economic Research Papers 2007-069.

- S. Levitt and J. A. List. 2007. "What do Laboratory Experiments Measuring Social Preferences tell us about the Real World", Journal of Economic Perspectives 21(2): 153174

- M. Rabin. 1993. "Incorporating Fairness into Game Theory and Economics," American Economic Review 83: 1281-1302.

- P. Zak and S. Knack. 2001. "Trust and growth," The Economic Journal 111: 295-321. 
Table A1: "Reduced" samples regressions (schooling $>12$ years)

$\begin{array}{lllll}\text { Free Sharing Exact } 0 \times 3 & 6,000 \times 3 & 12,000 \times 3\end{array}$

\begin{tabular}{|c|c|c|c|c|c|c|}
\hline & Free & Sharing & Exact & $0 \times 3$ & $6,000 \times 3$ & $12,000 \times 3$ \\
\hline \multicolumn{7}{|l|}{ BLOCK 1} \\
\hline e(money) & $\begin{array}{c}-0.000 * * * \\
{[0.000]}\end{array}$ & $\begin{array}{c}0.000 * * * \\
{[0.000]}\end{array}$ & $\begin{array}{l}-0.000 \\
{[0.000]}\end{array}$ & $\begin{array}{c}0.000^{\star \star *} \\
{[0.000]}\end{array}$ & $\begin{array}{c}0.000^{\star * *} \\
{[0.000]}\end{array}$ & $\begin{array}{c}0.000 * * * \\
{[0.000]}\end{array}$ \\
\hline \multicolumn{7}{|l|}{ BLOCK 2} \\
\hline female & $\begin{array}{c}0.026 \\
{[0.110]}\end{array}$ & $\begin{array}{c}-0.235^{\star \star} \\
{[0.098]}\end{array}$ & $\begin{array}{c}0.319 * \star \star \\
{[0.100]}\end{array}$ & $\begin{array}{c}0.006 \\
{[0.101]}\end{array}$ & $\begin{array}{c}-0.167^{*} \\
{[0.088]}\end{array}$ & $\begin{array}{l}-0.049 \\
{[0.087]}\end{array}$ \\
\hline white & $\begin{array}{l}0.309 * * \\
{[0.125]}\end{array}$ & $\begin{array}{c}-0.193^{\star} \\
{[0.116]}\end{array}$ & $\begin{array}{c}0.014 \\
{[0.110]}\end{array}$ & $\begin{array}{l}-0.045 \\
{[0.121]}\end{array}$ & $\begin{array}{c}-0.228^{\star *} \\
{[0.105]}\end{array}$ & $\begin{array}{c}-0.213^{\star \star} \\
{[0.105]}\end{array}$ \\
\hline black & $\begin{array}{c}-0.557 \\
{[0.600]}\end{array}$ & $\begin{array}{c}0.678 \\
{[0.563]}\end{array}$ & $\begin{array}{l}-0.378 \\
{[0.621]}\end{array}$ & $\begin{array}{c}-0.211 \\
{[0.406]}\end{array}$ & $\begin{array}{c}0.392 \\
{[0.497]}\end{array}$ & $\begin{array}{c}0.171 \\
{[0.226]}\end{array}$ \\
\hline indig & $\begin{array}{c}0.340 \\
{[0.485]}\end{array}$ & $\begin{array}{c}-0.625^{\star \star} \\
{[0.262]}\end{array}$ & $\begin{array}{c}0.362 \\
{[0.354]}\end{array}$ & $\begin{array}{c}-1.174^{\star \star} \\
{[0.598]}\end{array}$ & $\begin{array}{c}-0.696 \star \star \\
{[0.313]}\end{array}$ & $\begin{array}{c}-0.603^{\star *} \\
{[0.244]}\end{array}$ \\
\hline age & $\begin{array}{c}-0.023 \\
{[0.026]}\end{array}$ & $\begin{array}{l}-0.001 \\
{[0.022]}\end{array}$ & $\begin{array}{c}0.015 \\
{[0.023]}\end{array}$ & $\begin{array}{l}0.059 * \star \\
{[0.024]}\end{array}$ & $\begin{array}{c}0.012 \\
{[0.021]}\end{array}$ & $\begin{array}{c}0.017 \\
{[0.021]}\end{array}$ \\
\hline age2 & $\begin{array}{c}0.000 \\
{[0.000]}\end{array}$ & $\begin{array}{c}0.000 \\
{[0.000]}\end{array}$ & $\begin{array}{l}-0.000 \\
{[0.000]}\end{array}$ & $\begin{array}{l}-0.000 \\
{[0.000]}\end{array}$ & $\begin{array}{l}-0.000 \\
{[0.000]}\end{array}$ & $\begin{array}{l}-0.000 \\
{[0.000]}\end{array}$ \\
\hline educ $13-22$ & $\begin{array}{c}0.008 \\
{[0.026]}\end{array}$ & $\begin{array}{l}-0.002 \\
{[0.026]}\end{array}$ & $\begin{array}{c}-0.007 \\
{[0.025]}\end{array}$ & $\begin{array}{c}-0.056^{*} \\
{[0.029]}\end{array}$ & $\begin{array}{c}-0.001 \\
{[0.023]}\end{array}$ & $\begin{array}{c}-0.003 \\
{[0.023]}\end{array}$ \\
\hline
\end{tabular}

BLOCK 3

\begin{tabular}{rcccccc} 
married & 0.038 & 0.082 & -0.120 & 0.026 & 0.095 & -0.026 \\
& {$[0.145]$} & {$[0.141]$} & {$[0.137]$} & {$[0.132]$} & {$[0.126]$} & {$[0.123]$} \\
single & -0.219 & 0.189 & -0.008 & 0.131 & 0.111 & 0.135 \\
& {$[0.158]$} & {$[0.137]$} & {$[0.140]$} & {$[0.143]$} & {$[0.126]$} & {$[0.124]$} \\
wealth & -0.040 & 0.046 & -0.039 & 0.037 & $0.073^{\star \star}$ & $0.093^{\star \star \star}$ \\
& {$[0.036]$} & {$[0.033]$} & {$[0.031]$} & {$[0.036]$} & {$[0.030]$} & {$[0.030]$} \\
excluded & 0.060 & -0.045 & 0.112 & -0.045 & 0.167 & -0.045 \\
& {$[0.138]$} & {$[0.134]$} & {$[0.126]$} & {$[0.142]$} & {$[0.123]$} & {$[0.119]$} \\
chief & -0.032 & 0.122 & -0.153 & -0.059 & -0.108 & 0.092 \\
& {$[0.129]$} & {$[0.113]$} & {$[0.119]$} & {$[0.122]$} & {$[0.107]$} & {$[0.108]$} \\
\hline & & & & & & \\
$\mathrm{N}$ & 625 & 625 & 625 & 624 & 624 & 624 \\
\hline Pseudo R2 & 0.05 & 0.04 & 0.02 & 0.08 & 0.05 & 0.04 \\
\hline
\end{tabular}

[Robust standard errors]; * significant at $10 \%$; ** significant at $5 \%$; $* \star *$ significant at $1 \%$ 
Table A2: "Reduced" sample ( $17<$ age $<25)$

\begin{tabular}{|c|c|c|c|c|c|c|}
\hline & Free & Sharing & Exact & $0 \times 3$ & $6,000 \times 3$ & $12,000 \times 3$ \\
\hline \multicolumn{7}{|l|}{ BLOCK 1} \\
\hline $\mathrm{e}$ (money) & $\begin{array}{c}-0.000 \star \star \star \star \\
{[0.000]}\end{array}$ & $\begin{array}{c}0.000^{\star * *} \\
{[0.000]}\end{array}$ & $\begin{array}{c}-0.00{ }^{\star \star} \\
{[0.000]}\end{array}$ & $\begin{array}{c}0.000^{\star \star *} \\
{[0.000]}\end{array}$ & $\begin{array}{c}0.000 * * * \\
{[0.000]}\end{array}$ & $\begin{array}{c}0.000 * \star \star \\
{[0.000]}\end{array}$ \\
\hline \multicolumn{7}{|l|}{ BLOCK 2} \\
\hline Female & $\begin{array}{c}0.103 \\
{[0.123]}\end{array}$ & $\begin{array}{c}-0.098 \\
{[0.126]}\end{array}$ & $\begin{array}{c}0.048 \\
{[0.118]}\end{array}$ & $\begin{array}{c}0.118 \\
{[0.127]}\end{array}$ & $\begin{array}{c}0.061 \\
{[0.114]}\end{array}$ & $\begin{array}{c}-0.058 \\
{[0.107]}\end{array}$ \\
\hline White & $\begin{array}{c}0.237^{\star} \\
{[0.139]}\end{array}$ & $\begin{array}{c}-0.015 \\
{[0.140]}\end{array}$ & $\begin{array}{l}-0.250^{\star} \\
{[0.138]}\end{array}$ & $\begin{array}{c}0.119 \\
{[0.146]}\end{array}$ & $\begin{array}{c}-0.280 * * \\
{[0.127]}\end{array}$ & $\begin{array}{c}-0.257^{\star \star} \\
{[0.122]}\end{array}$ \\
\hline Black & $\begin{array}{c}-0.114 \\
{[0.489]}\end{array}$ & $\begin{array}{c}0.339 \\
{[0.346]}\end{array}$ & $\begin{array}{l}-0.368 \\
{[0.281]}\end{array}$ & $\begin{array}{c}0.368 \\
{[0.428]}\end{array}$ & $\begin{array}{c}0.037 \\
{[0.391]}\end{array}$ & $\begin{array}{c}0.071 \\
{[0.404]}\end{array}$ \\
\hline Indig & $\begin{array}{c}-0.095 \\
{[0.520]}\end{array}$ & $\begin{array}{c}-0.491 \\
{[0.491]}\end{array}$ & $\begin{array}{c}0.458 \\
{[0.494]}\end{array}$ & $\begin{array}{c}-0.863^{\star \star} \\
{[0.421]}\end{array}$ & $\begin{array}{l}-0.412^{*} \\
{[0.236]}\end{array}$ & $\begin{array}{c}-0.337^{*} \\
{[0.191]}\end{array}$ \\
\hline $17<$ Age $<25$ & $\begin{array}{l}-0.540 \\
{[0.559]}\end{array}$ & $\begin{array}{c}-0.638 \\
{[0.576]}\end{array}$ & $\begin{array}{c}1.607^{\star \star *} \\
{[0.550]}\end{array}$ & $\begin{array}{c}-1.349 * \star \\
{[0.601]}\end{array}$ & $\begin{array}{c}-0.142 \\
{[0.533]}\end{array}$ & $\begin{array}{c}0.083 \\
{[0.521]}\end{array}$ \\
\hline age2 & $\begin{array}{c}0.013 \\
{[0.014]}\end{array}$ & $\begin{array}{c}0.015 \\
{[0.014]}\end{array}$ & $\begin{array}{c}-0.038 * \star \star \\
{[0.013]}\end{array}$ & $\begin{array}{l}0.033^{\star \star} \\
{[0.015]}\end{array}$ & $\begin{array}{c}0.004 \\
{[0.013]}\end{array}$ & $\begin{array}{l}-0.002 \\
{[0.013]}\end{array}$ \\
\hline educ & $\begin{array}{c}-0.058^{\star *} \\
{[0.029]}\end{array}$ & $\begin{array}{c}0.078^{\star * *} \\
{[0.029]}\end{array}$ & $\begin{array}{l}-0.038 \\
{[0.031]}\end{array}$ & $\begin{array}{c}-0.086^{\star \star \star} \\
{[0.032]}\end{array}$ & $\begin{array}{c}0.030 \\
{[0.027]}\end{array}$ & $\begin{array}{l}0.053^{\star *} \\
{[0.025]}\end{array}$ \\
\hline \multicolumn{7}{|l|}{ BLOCK 3} \\
\hline married & $\begin{array}{c}-0.184 \\
{[0.371]}\end{array}$ & $\begin{array}{l}-0.353 \\
{[0.285]}\end{array}$ & $\begin{array}{l}0.877^{\star *} \\
{[0.344]}\end{array}$ & $\begin{array}{c}0.489 \\
{[0.379]}\end{array}$ & $\begin{array}{c}0.294 \\
{[0.340]}\end{array}$ & $\begin{array}{l}-0.180 \\
{[0.385]}\end{array}$ \\
\hline single & $\begin{array}{l}-0.006 \\
{[0.169]}\end{array}$ & $\begin{array}{l}-0.143 \\
{[0.199]}\end{array}$ & $\begin{array}{c}0.070 \\
{[0.195]}\end{array}$ & $\begin{array}{l}-0.163 \\
{[0.191]}\end{array}$ & $\begin{array}{c}0.038 \\
{[0.180]}\end{array}$ & $\begin{array}{l}-0.101 \\
{[0.166]}\end{array}$ \\
\hline wealth & $\begin{array}{l}-0.081^{*} \\
{[0.043]}\end{array}$ & $\begin{array}{l}0.107^{\star \star} \\
{[0.043]}\end{array}$ & $\begin{array}{l}-0.069 * \\
{[0.039]}\end{array}$ & $\begin{array}{c}0.001 \\
{[0.045]}\end{array}$ & $\begin{array}{l}0.089 * * \\
{[0.041]}\end{array}$ & $\begin{array}{c}0.112^{\star \star \star} \\
{[0.037]}\end{array}$ \\
\hline excluded & $\begin{array}{c}0.114 \\
{[0.149]}\end{array}$ & $\begin{array}{c}-0.183 \\
{[0.143]}\end{array}$ & $\begin{array}{c}0.159 \\
{[0.145]}\end{array}$ & $\begin{array}{l}-0.302^{*} \\
{[0.182]}\end{array}$ & $\begin{array}{l}-0.191 \\
{[0.143]}\end{array}$ & $\begin{array}{l}-0.103 \\
{[0.138]}\end{array}$ \\
\hline chief & $\begin{array}{l}-0.220 \\
{[0.242]}\end{array}$ & $\begin{array}{c}0.011 \\
{[0.197]}\end{array}$ & $\begin{array}{c}0.009 \\
{[0.177]}\end{array}$ & $\begin{array}{c}0.146 \\
{[0.282]}\end{array}$ & $\begin{array}{c}0.038 \\
{[0.185]}\end{array}$ & $\begin{array}{c}0.161 \\
{[0.196]}\end{array}$ \\
\hline $\mathrm{N}$ & 374 & 374 & 374 & 374 & 374 & 374 \\
\hline Pseudo R2 & 0.06 & 0.06 & 0.03 & 0.10 & 0.06 & 0.05 \\
\hline
\end{tabular}

[Robust standard errors]; * significant at $10 \%$; ** significant at $5 \%$; ** significant at $1 \%$ 